\title{
SUSTAINABILITY AND TAILINGS MANAGEMENT IN THE MINING INDUSTRY: PASTE TECHNOLOGY
}

\author{
*Erol YILMAZ \\ Department of Applied Sciences, Université du Québec en Abitibi-Témiscamingue, Canada, erol.yilmaz@uqat.ca \\ (iD) https://orcid.org/0000-0001-8332-8471 \\ Elif YILMAZ \\ Department of Mining Engineering, Karadeniz Technical University, Turkey, elifkoc@ktu.edu.tr \\ (iD) https://orcid.org/0000-0001-8789-0007 \\ Research Article \\ DOI:10.22531/muglajsci.383095
}

Received: 24.01.2018, Accepted: 16.05 .2018

*Corresponding author

\begin{abstract}
In this study, the basic principles of paste technology which has been implemented successfully in the mining industry for both waste volume reduction and environmental impact reduction were investigated. In the past two decades, paste technology has progressed from a research-based mine backfill idea to a widely accepted and cost-effective fill system with the potential to totally change the approach tailings are disposed on the surface. Application of paste tailings for modern mines was shown experimentally by laboratory and field testing, focusing on intrinsic (e.g., tailings, cement and mix water properties) and extrinsic (e.g., in situ mixing, placement and curing conditions) parameters. Results indicate that use of paste tailings as backfilling and disposal in the mining industry as an innovative and environmentally sound system can guarantee operational continuity by reducing environmental (e.g., tailings dam failure, acidic water formation) and financial concerns over the mine's life. Finally, paste technology enables mining operators to better manage their problematic tailings produced in the mineral processing plants.

Keywords: Tailings, Sustainability, Paste technology, Mining industry, Environmental impact

\section{MADENCİLİK ENDÜSTRİSINDE SÜRDÜRÜLEBİLİRLİK VE ATIK YÖNETIMII: MACUN TEKNOLOJISII}

$\ddot{0} \mathbf{z}$

Bu çalışmada, hem atık hacim azaltma hem de çevresel etki azaltma için madencilik endüstrisinde başarılı bir şekilde uygulanmakta olan macun teknolojisinin temel prensipleri incelenmiştir. Geçmiş yirmi yllda, macun teknolojisi araştırmaya dayalı maden dolgu fikrinden atıkların yerüstünde depolanması yaklaşımını tümüyle değiştirme potansiyelli yaygın olarak kabul görmüs, etkin maliyetli bir dolgu sistemine ilerlemiştir. Modern madenler için macun atık uygulaması içsel (örneğin atık, çimento ve karışım suyu özellikleri) ve dışsal (örneğin yerinde karıştırma, yerleştirme ve kür koşulları) parametrelere odaklanarak laboratuvar ve arazi testleriyle deneysel olarak gösterilmişstir. Sonuçlar göstermektedir ki yenilikçi ve çevreye uyumlu bir sistem olarak macun atıklarının madencilik endüstrisinde dolgu ve depolama olarak kullanılması maden ömrü boyunca çevresel (örneğin atık baraj yıkılması, asidik su oluşumu) ve finansal kaygıları azaltarak operasyonel sürekliliği garanti edebilir. Son olarak, macun teknolojisi cevher hazırlama ve zenginleştirme tesislerinde üretilen problematik atıklarını daha iyi yönetmek için maden operatörlerine izin vermektedir

Anahtar Kelimeler: Atıklar, Sürdürülebilirlik, Macun teknolojisi, Madencilik endüstrisi, Çevresel etki

Cite

Yılmaz, E., Yılmaz, E., (2018). "Sustainability and tailings management in the mining industry: Paste technology”, Mugla Journal of Science and Technology, 4(1), 16-26.

\section{Introduction}

The mining industry has a big potential to affect industrialized and developing economies by providing employment, income, and opportunities for economic growth and diversification. But, it certainly creates the huge volumes of environmentally harmful tailings that need to be managed properly to diminish or remove the environmental impact. Sulfidic tailings contain pyrite and iron minerals which can react with air and water to form sulfuric acid and dissolved iron [1, 2]. Waste rocks are basically defined as a coarse-sized material resulting from the decomposition of unwanted mine rocks by weathering during mining without being processed while tailings are defined as the fine-sized material left over after the process of removing the valuable constituents from the uneconomic fraction of the run-of-the mine ore [3]. The tailings management poses many challenges on the mining and mineral industries, frequently concerning the negative impact on environment. To stop the environmental pollution and reach sustainable operations for most modern mines around the world, there are a variety of different tailings management ways $[4,5,6]$.

One practical solution is to use the tailings as paste backfill for underground mines and as paste disposal for surface facilities. 
Using the paste as fill and storage has become a vital operating system in recent years due to increased tailings use, reduced rehabilitation costs and environmental impact, and improved ore extraction and safety conditions [7]. Autonomously, the exploration and extraction of the ores at modern mines need to be maximized while minimizing their costs [8]. The need for a low cost and efficient tailings management technique in mines is driving mine operators to consider using the tailings as a raw material source for hard rock mines worldwide. In recent times, paste backfill was used for underground mines as ground support and waste reduction element $[9,10]$. A new way of tailings management has also been proposed recently by mines to replace the usual methods. The principle of this way is to use dewatered tailings (containing 70-75\% solids) and drop them surface in paste form $[11,12]$. Figure 1 shows a schematic view of sustainable waste management. Certainly, paste technology offers many technical, operational, financial and environmental benefits for the secure management of destructive mining wastes $[7,13]$. The key benefits of the use of paste backfill include: reduced binder amount for equal strength, decreased quantity of the paste backfill linked with water, reduced labor necessities, faster mining cycle, reduced maintenance, and improved mining activities. In addition, the main advantages of surface paste tailings disposal include: reduced storage footprint, decreased water consumption, reduced mine rehabilitation and closure costs, and decreased operational risks. The paste is defined as a non-settling and flowable material of solids and water which shows negligible water bleed when sitting freely (Figure 2). It has a low yield stress of $200 \mathrm{kPa}$ and a slump consistency of up to 10 inches $[14,15]$. Founded on its underground or surface application, cement and/or sand can be added to the paste without having any detrimental effect on its homogeneous nature and flow characteristics $[16,17]$.

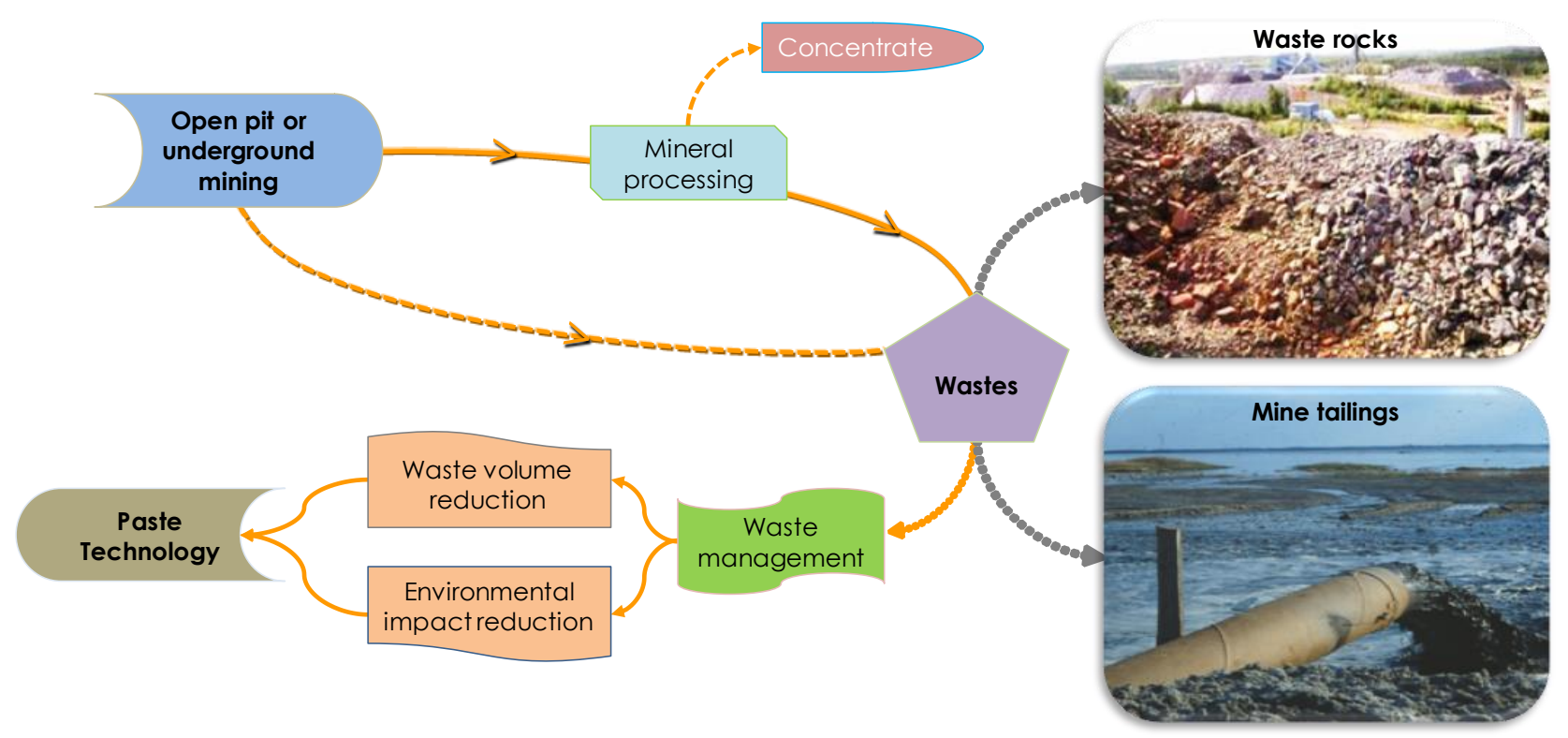

Figure 1. Schematic view of sustainable mining waste management with paste technology

Cemented paste backfill (CPB) is a high density mixture that consists frequently of total or deslimed tailings (75-85 wt\% solids), hydraulic binders (2-7 wt\%) and enough water (6-10 inches) to ease the paste's transport to underground stopes by gravity and/or pump [14, 18-21]. CPB are used for backfilling stopes in underground mines. The quality and behavior of the CPB material are not only controlled by the internal material properties, but also their external field conditions. Different scientific works have been so far done on both laboratory-made paste backfills [22-24] and field paste backfills [25-29]. Due to the fact that field test works are a challenging duty and risky, different experimental setups or methods were used recently in order to mimic the paste backfill's field conditions at laboratory $[9,30]$. Hence, measuring CPB's performance is vital for a capable mine backfill design. In recent times, surface paste disposal (SPD) has been proposed in the mining industry as an alternative system to conventional mine tailings disposal methods for above ground storage [31, 32]. Derived from the backfill technique being used for underground modern mines, it can be implemented with or without cement addition. It is worth mentioning that the SPD system has been used less often by modern mines worldwide as a result of a fairly new technique for the tailings management. The Bulyanhulu mine
(Tanzania) was the first gold mine to adopt this system [33]. The non-cemented paste tailings contain a solid concentration of $73 \mathrm{wt} \%$ which corresponds to a slump consistency of 250 $\mathrm{mm}$. The dewatered tailings are placed sequentially in $30 \mathrm{~cm}$ layers (each layer builds up every 5 days) which are allowed to dry out before the next paste tailings layer is put in place. It is believed that applying the paste technology as both tailings disposal and mine backfill purposes, as shown in Figure 2, will bring a new light to the sustainable mining waste management for most modern mines worldwide.

\section{Materials and Methods}

\subsection{Laboratory and field test systems}

In this study, the two experimental laboratory set-ups were used in order to better study both cemented paste backfill and surface paste disposal applications. Figure 3 shows photos of laboratory apparatus used to better imitate the properties of underground paste backfills and mini field cells used to better duplicate the application of surface paste disposal. The used laboratory apparatus (Figure 3a) is consisted of three main parts: i) a top loading platen in order to apply a vertical total stress of up to $800 \mathrm{kPa}$, ii) a transparent and plastic specimen container $(\mathrm{D} \times \mathrm{H}=102 \times 204 \mathrm{~mm})$ in order to hold the paste 
tailings or backfill sample, and iii) a bottom drainage hole in order to collect the water drained from paste backfill samples. Additional information on this apparatus and its preliminary works can be found in $[11,28]$.

The field conditions of paste backfills can be well simulated by this apparatus. After each test, CPB specimen is first extracted and then subjected to strength testing. Two mini experimental field cells were used to better study the application of SPD. The first cell is designed by filling partly with tailings having a cement rate of $2 \%$ and termed as cemented cell (CC) while the second cell is designed by filling completely with paste tailings without cement and termed as uncemented cell (UC).

The mini field cells (Figure $3 \mathrm{~b}$ ) were designed as an inverted pyramid, with a basal area $(8.1 \times 2 \mathrm{~m})$ and a top surface area $(15 \times 7.9 \mathrm{~m})$. Paste tailings are prepared in surface paste fill plant and sent to the storage site using a ready-mix truck. Paste tailings are deposited in thin layers (total 10 layers and each 10 $\mathrm{cm}$ thickness).

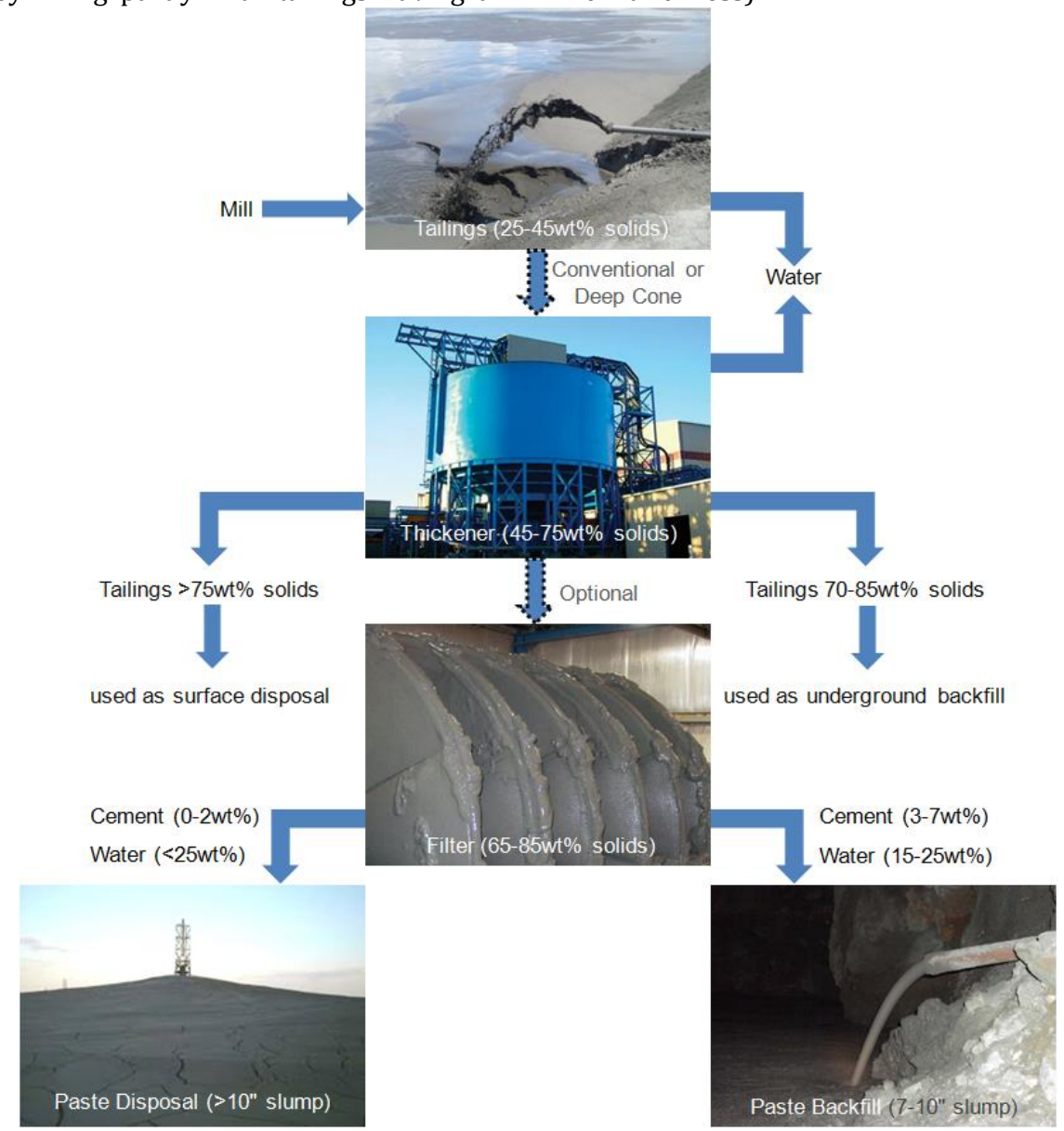

Figure 2. A schematic view of the fundamental stages of paste technology considered for modern mines
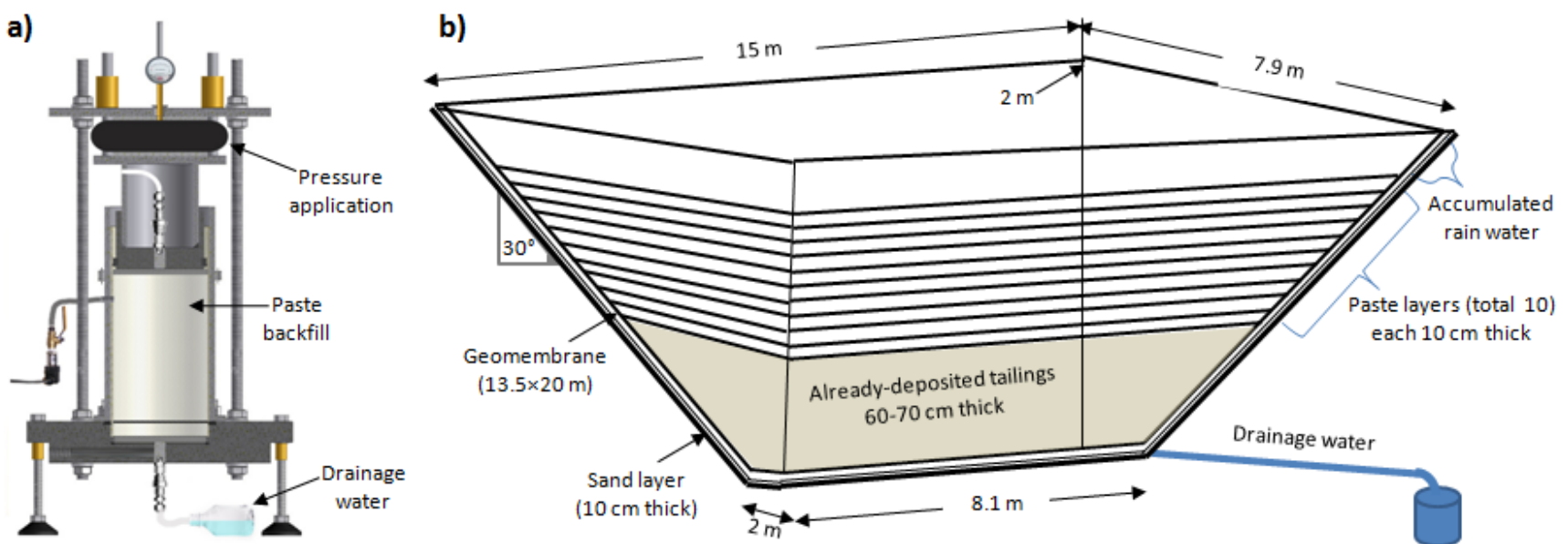

Figure 3. Schematic view of laboratory apparatus and field experimental cells used in this study

\subsection{Characterization of paste backfill ingredients}

Tailings were collected from the paste plant of a polymetallic mine. The collected samples were received in sealed plastic containers to avoid any oxidation and prepared to portray the material properties of paste tailings. Malvern Mastersizer laser diffraction-type particle size analyzer was used to measure the grain size distributions of paste tailings (Figure 4). 
The laboratory analyses show that tailings have an average water content $w$ of $24.5 \mathrm{wt} \%$, a specific gravity $G_{\text {s }}$ of 3.3 , a specific surface $S_{\mathrm{s}}$ of $2.5 \mathrm{~m}^{2} / \mathrm{g}$, a total porosity $n_{\text {tot }}$ of $48.7 \%$, an optimum water content $w_{\text {opt }}$ of $9.8 \mathrm{wt} \%$, a maximum dry unit weight $\gamma_{\mathrm{dmax}}$ of $23.6 \mathrm{kN} / \mathrm{m}^{3}$, a relative compaction $R_{\mathrm{c}}$ of $93 \mathrm{wt} \%$, a liquid limit $w_{\mathrm{L}}$ of $22.8 \mathrm{wt} \%$, a plastic limit $w_{\mathrm{P}}$ of $17.4 \mathrm{wt} \%$, a liquidity index $L I$ of $1.3 \mathrm{wt} \%$ and a plastic index PI of $4.8 \mathrm{wt} \%$. From the Atterberg limit results, the tailings can be designated as CL-ML, silty clay. Most of the grain size falls into the silts to fine sand range, having a clay-sized grain of $9.5 \%$. Tailings can be also classified as medium tailings (amount of grains finer than $20 \mu \mathrm{m} \sim 44 \%$ ) according to the fines content.

The mineralogical composition of paste tailings was inspected using both a Bruker AXS D8 Advance X-ray diffractometer XRD and a Hitachi ${ }^{\circledR} 3500-\mathrm{N}$ scanning electron microscopy coupled

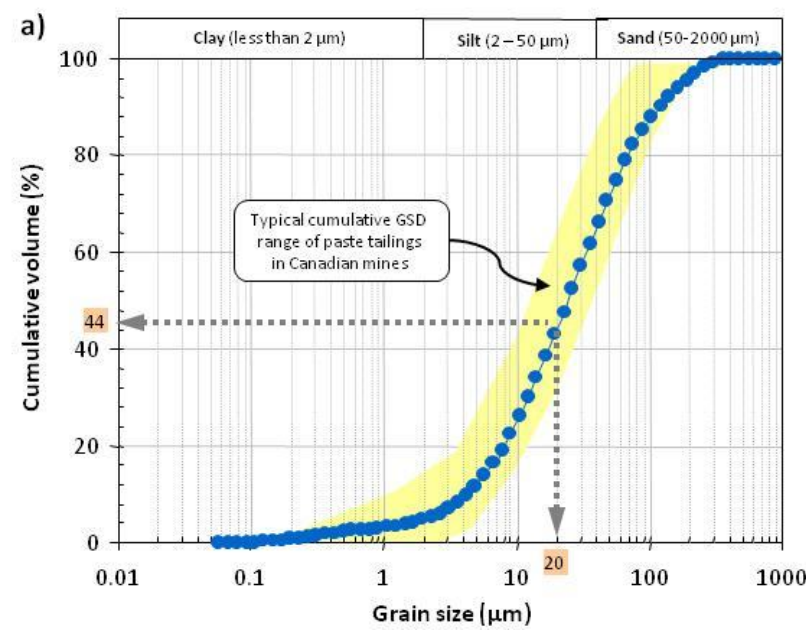

Figure 4. Grain size distribution of paste tailings: a) cumulative and b) incremental curves
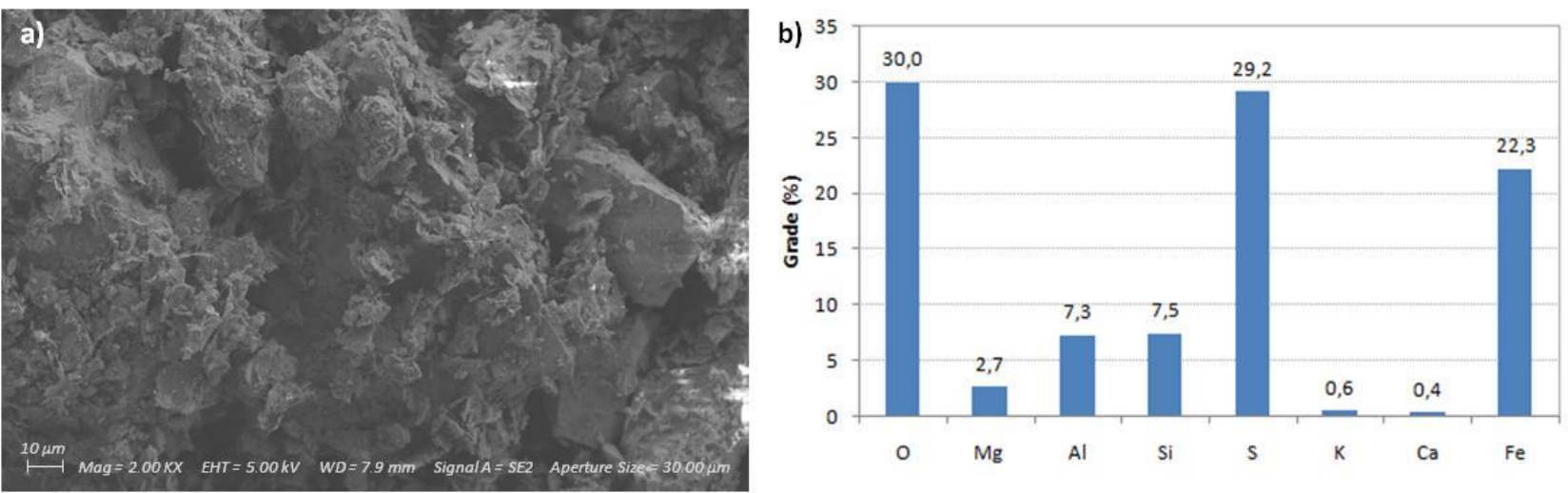

Figure 5. Mineralogical and chemical compositions of paste tailings: a) SEM and b) EDS analyses

A blended cement consisting of normal Portland cement type 10 (PCI) and ground granulated blast furnace slag (Slag) in a ratio of $20: 80 \%$ was used for paste backfill applications while only PCI was used for SPD applications. The cement contents used during the experiments were respectively $4.5 \mathrm{wt} \%$ and 2 $\mathrm{wt} \%$ for both backfilling and disposal purposes. The chemical characteristics of both binders and water were summarized in Table 1 . The two different water (e.g., tailings pore water and municipal tap water) were utilized as mixing water. ICP-AES (Perkin Elmer Optima 3100RL) was employed to analyze the chemical composition of mixing water and that of the drainage water collected during the paste tailings deposition. $\mathrm{pH}$, redox potential Eh and electrical conductivity EC were measured using a Benchtop pH/ISE Meter Orion Model 920A coupled with

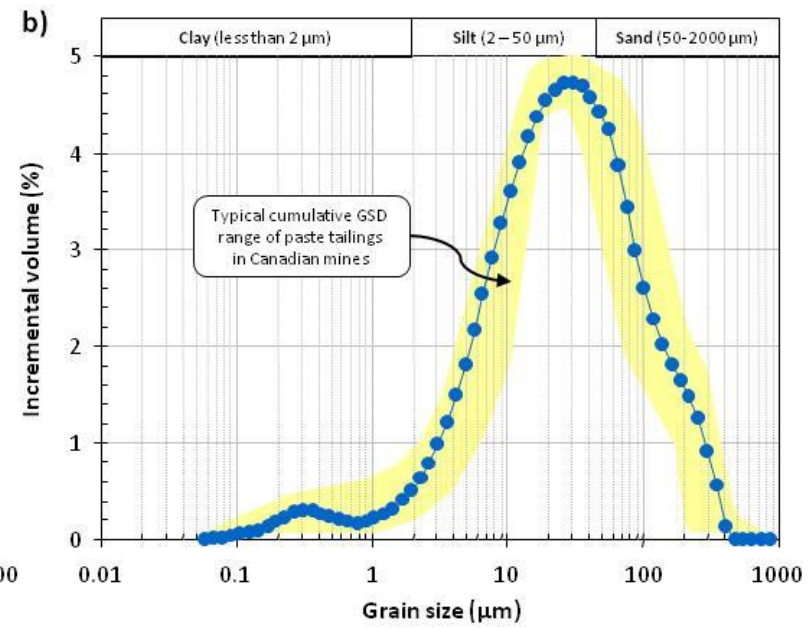

with energy dispersive X-ray spectroscopy SEM-EDS (Figure $5 a)$. The XRD results revealed the dominance of quartz (53.5 $\mathrm{wt} \%)$ and pyrite $(27.5 \mathrm{wt} \%)$ phases within tailings. To better identify the mineral phases' chemical composition, the EDS analysis was also performed and the results obtained are shown in Figure 5b. SEM-EDS results confirm that sulfur $(\mathrm{S}=$ $29.2 \%)$ and iron $(\mathrm{Fe}=22.3 \%)$ leading to acid and sulfate production were the two main elements within the studied paste tailings. Silicon $(\mathrm{Si}=13.5 \%)$ and aluminum $(\mathrm{Al}=7.3 \%)$ precipitate in tailings as stable hydroxides while a small part of calcium ( $\mathrm{Ca}=0.4 \%)$ precipitates as expansive gypsum. As well, the remaining CPB ingredients such as hydraulic binders and mixing water were characterized as follows. 
curing. The applied pressures exhibit a paste filled stope height of $18 \mathrm{~m}$ which was calculated from vertically-applied total pressures (pv) and knowing the paste backfill's wet unit weight $\gamma(23.1 \mathrm{kN} / \mathrm{m} 3)$. Note that this study does not consider the effect of effective stress. For the safe application of surface paste disposal, paste tailings are first prepared at the paste plant and then delivered by using a ready-mix truck to two mini

Table 1. Chemical characteristics of hydraulic binders and mixing water used in this study

\begin{tabular}{|c|c|c|c|c|c|c|}
\hline Element & $\begin{array}{l}\text { Detection limit } \\
(\mathrm{mg} / \mathrm{L})\end{array}$ & $\begin{array}{l}\text { PCI 100\% } \\
\text { (mg/L) }\end{array}$ & $\begin{array}{l}\text { Slag 100\% } \\
(\mathrm{mg} / \mathrm{L})\end{array}$ & $\begin{array}{c}\text { Blended cement } \\
(\mathrm{mg} / \mathrm{L})\end{array}$ & $\begin{array}{c}\text { Tailings pore } \\
\text { water }(\mathrm{mg} / \mathrm{L})\end{array}$ & $\begin{array}{c}\text { Tap water } \\
(\mathrm{mg} / \mathrm{L})\end{array}$ \\
\hline $\mathrm{Al}$ & 0.010 & 2.57 & 5.42 & 4.44 & 0.21 & 0.01 \\
\hline $\mathrm{Ba}$ & 0.001 & 0.01 & 0.15 & 0.03 & 0.05 & 0.01 \\
\hline $\mathrm{Ca}$ & 0.030 & 47.0 & 22.45 & 30.6 & 559 & 40.9 \\
\hline $\mathrm{Fe}$ & 0.006 & 1.71 & 0.38 & 0.45 & 0.01 & 0.06 \\
\hline $\mathrm{K}$ & 0.003 & 0.69 & 0.42 & 0.46 & 0.29 & 0.84 \\
\hline $\mathrm{Mg}$ & 0.001 & 1.33 & 6.81 & 3.73 & 1.83 & 2.27 \\
\hline $\mathrm{Mn}$ & 0.002 & 0.03 & 0.75 & 0.14 & 0.01 & 0.01 \\
\hline $\mathrm{Na}$ & 0.004 & 1.57 & 1.49 & 1.51 & 0.05 & 0.01 \\
\hline $\mathrm{S}$ & 0.033 & 1.47 & 1.31 & 1.34 & 1630 & 46.0 \\
\hline $\mathrm{Si}$ & 0.020 & 9.12 & 16.9 & 14.5 & 0.89 & 0.90 \\
\hline $\mathrm{Ti}$ & 0.002 & 0.15 & 0.37 & 0.29 & 0.01 & 0.02 \\
\hline $\mathrm{Zn}$ & 0.005 & 0.03 & 0.01 & 0.01 & 0.11 & 0.10 \\
\hline
\end{tabular}
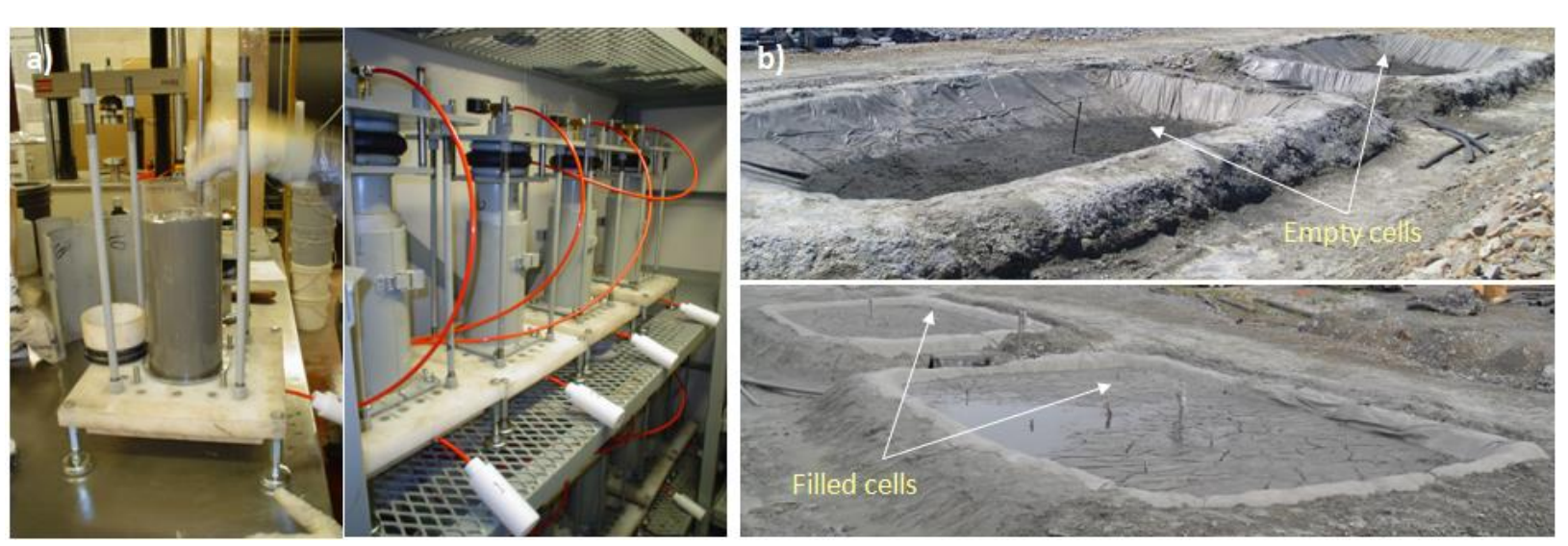

Figure 6. The tailings sample preparation and placement conditions: a) CPB and b) SPD applications
To get a flat layer of tailings, a Topcon ${ }^{\circledR} R L-H 3 C$ Rotating Laser was used across the field cells. Only first layer is kept cemented in order to show the effect of cement addition as a barrier layer on mitigation and/or prevention of acid mine drainage or tailings oxidation. In case of cemented cell, the binder rate used during the experiments was only $2 \%$ by dry weight of paste tailings. The selected binding agent was normal Portland cement.

\subsection{Unconfined compression tests}

The unconfined compression tests were conducted only on CPB samples by using a stiff universal testing machine (MTS Sintech 10/GL load frame) having $50 \mathrm{kN}$ load capacity and $1 \mathrm{~mm} / \mathrm{min}$ deformation rate. The three tests were undertaken on samples to reach an average strength value. A small portion of paste samples were oven-dried for about 3 days at $45^{\circ} \mathrm{C}$ temperature until mass stabilization to measure their final water content. To evaluate the influence of curing time the strength testing were done on 7-, 14-, and 28-day cured paste backfill samples. Note that no mechanical strength testing was conducted for SPD application.

\subsection{Geotechnical and microstructural tests}

The geotechnical index tests were done on representative samples broken after strength testing. The water content and specific gravity of cemented paste fill samples were initially determined. Using these two data ( $w$ and $G_{s}$ ), the remaining construction cells (Figure 6b). The paste tailings containing a slump value ranging from 200 to $290 \mathrm{~mm}$ were disposed in these mini cells with or without cement. Each disposal design (e.g., cemented and uncemented) was made up of 10 paste tailings layers, each about $10 \mathrm{~cm}$ thickness. parameters (void ratio $e$ and degree of saturation $S_{\mathrm{r}}$ ) can be calculated. The microstructural properties of paste backfill samples were also determined by a Micromeritics Autopore III 9420 mercury intrusion porosimeter (MIP) which allows applying a pressure of up to $414 \mathrm{MPa}$ and measuring throat pore diameter of up to $0.003 \mu \mathrm{m}$. The MIP testing was analyzed consistent with the ASTM D 4404 standard. After strength testing, small cylindrical samples $(D \times H=12 \times 24 \mathrm{~mm})$ were taken from the middle point of samples. For a given paste backfill mix recipe, at least two MIP tests were done for reaching an average value.

\section{Results and Discussion}

\subsection{Effect of curing and stress conditions on strength properties of paste backfills}

Figure $7 \mathrm{a}$ exhibits the influence of curing conditions on the strength development of paste backfill samples containing $4.5 \%$ cement as a function of curing time. The different paste backfill samples (consolidated, drained and undrained ones) were compared with the curing times of 7, 14 and 28 days. Generally, consolidated backfills produced always the best strengths among others, regardless of the curing time. For example, the strength of consolidated backfills cured at 28 days was $2.9 \mathrm{MPa}$ while the strength of drained backfills was $1.5 \mathrm{MPa}$, indicating a mechanical strength increase of 50\%. Observation can make that the variation of strength reduces somewhat with 
increasing curing time due to reduced void spaces within the paste backfill after the formation of cement hydration products. Another reason why consolidated paste backfills present higher strength gains than other types of backfilling (drained or nondrained) may be well linked with drainage water and consolidation loadings. The drainage of free water available in fresh backfills causes a reduction in the overall porosity of filling and hence the higher strength. The drainage of free water also plays a significant role on cement hydration, leading to denser materials.

Figure $7 \mathrm{~b}$ shows a change in the strength of stress increase to $4.5 \%$ cemented paste backfills under during the early stages of curing. The equal strength of paste backfill samples increases with incremental pressure for a given mix recipe. At a curing time of 28 days, the paste backfill strength were respectively 2.1 $\mathrm{MPa}$, 2.5 $\mathrm{MPa}$, and 2.7 $\mathrm{MPa}$ for a vertical stress application

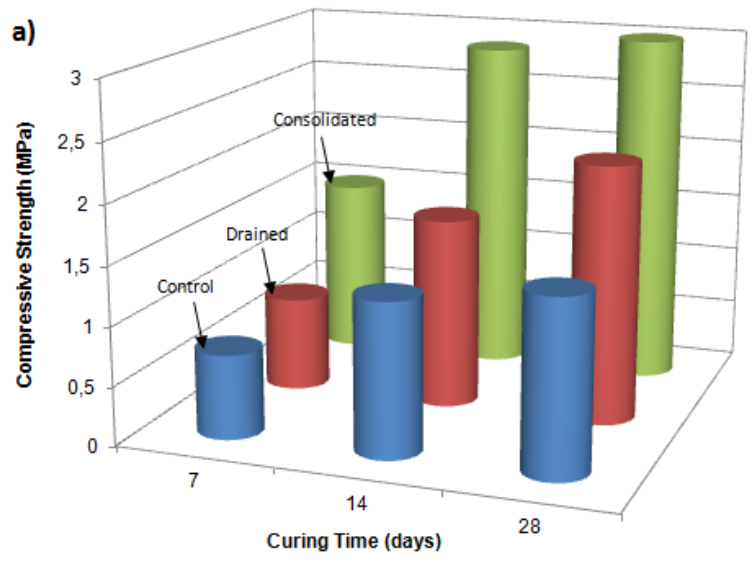

of $400 \mathrm{kPa}, 600 \mathrm{kPa}$ and $800 \mathrm{kPa}$, when comparing with a strength gain of $1.6 \mathrm{MPa}$ of non-drained backfills cured under 0 $\mathrm{kPa}$. A significant increase of $50 \%$ in pressure (vertical stress is increased from $400 \mathrm{kPa}$ to $800 \mathrm{kPa}$ ) produced a $29 \%, 25 \%$, and $21 \%$ increase of strength for a curing time of 7,14 and 28 days, respectively. Increasing the pressure leads to an increase of drainage water, which may have favored better hydration process due to over-saturation of dissolved ions. Application of stress during the early stages of curing could increase the corresponding paste backfill's strength. Overall, if the stress is applied right before the start of curing which contributes to paste's hardening, as is being practiced in this study, the rate of strength increase, the final strength of paste backfill become higher, compared with the application of self-weight or timedependent consolidation stress after the completion of cement hydration for paste backfill samples.

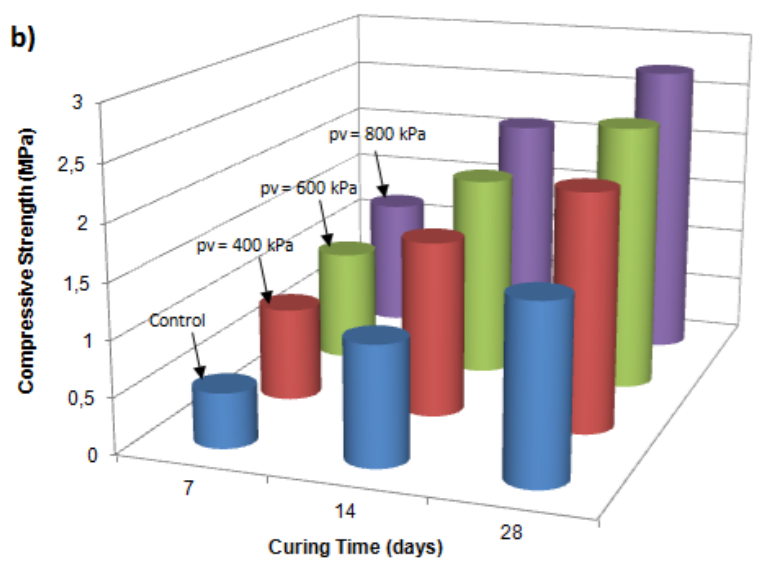

Figure 7. Change in the strength of different backfills in terms of a) curing and b) stresses conditions

\subsection{Effect of stope depth on strength properties of field paste backfills}

This distinction is important in terms of groundwater flow, which has very different characteristics in the fractures and conduits compared to the bulk of the rock. Figure 8 shows the evaluation of strength acquisition with curing time for $4.5 \mathrm{wt} \%$ binder paste backfills placed in an underground stope, obtained at different depths from the top of paste-filled stope. The strength gain increases with increasing stope depth for a given curing time, following identical trend as over- burden pressure $\left(\sigma_{\mathrm{v}}=\gamma * h\right)$. At 28 days, a strength gain of $1.6 \mathrm{MPa}, 2.1 \mathrm{MPa}, 2.5$ $\mathrm{MPa}, 2.6 \mathrm{MPa}, 2,7 \mathrm{MPa}$ and $2.9 \mathrm{MPa}$ were obtained from paste backfill samples at a stope depth of $0 \mathrm{~m}, 4 \mathrm{~m}, 8 \mathrm{~m}, 12 \mathrm{~m}, 16 \mathrm{~m}$ and $20 \mathrm{~m}$, respectively. This well proves that the mechanical strength of paste-filled stopes increases from the top to the bottom due to the consolidation effect. For a curing time of 7 , 14 and 28 days, the strength of backfills located at the bottom of the stope was respectively $81 \%, 64 \%$ and $51 \%$ higher than that of backfills located at the top of the stope.

The relative density of consolidated paste backfills increases with increasing stope depth, therefore decreasing void ratios as a result of effective stress during curing. This is because the lower the void ratio, the closer the cemented paste fill particle packing, and hence, the lower the friction angle that develops and the stronger the cemented paste fill material. Experiences indicate a relatively lower porosity and higher strength gain near the bottom of paste backfilled stope and a higher porosity (or void ratio) and lower mechanical strength near the top of paste backfilled stope at modern mines. For an efficient paste backfill mix design, it is vital to better evaluate the stress distribution in cemented paste backfill samples, which often evolves over placement conditions.

a)

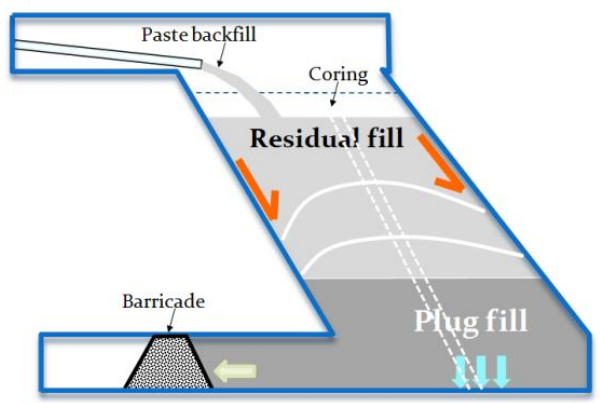

b)

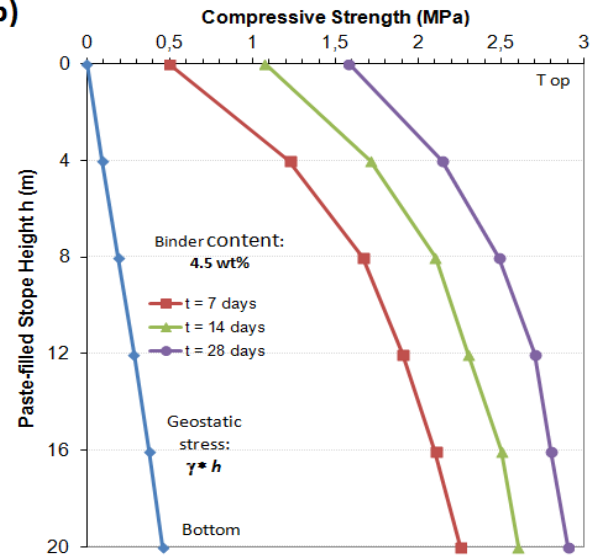

Figure 8. Assessment of stope depth effect on paste backfill: a) schematic view and b) test results 


\subsection{Effect of paste layer addition on SPD's water content and degree of saturation}

Figure 9 shows the evaluation of volumetric water content VWC measured in paste layers $1,3,5,8$ and 10 for field cells with or without cement, intended for SPD application. For the first layer, the volumetric water content value of paste tailings layer within the cemented cell CC is the lowest (0.46) when comparing with the one obtained from paste layer within the uncemented cell UC (0.48). The remaining paste tailings layers always exhibit the same trend where the uncemented cell UC specifies lower water contents than cemented cell CC mainly because of full water saturation of cemented paste layer which is assumed to be crucial for the maximal reduction of oxygen transport through the cover. The volumetric water content in paste tailings layer $3,5,8$ and 10 increases mainly because of re-saturation by free water drained after the layer of the paste tailings placed is fully settled. The main part of water flowed through desiccation crack network on surface paste disposal reaches and then stay in cemented ( $2 \mathrm{wt} \%$ ) layer, which acts as a barrier cover.

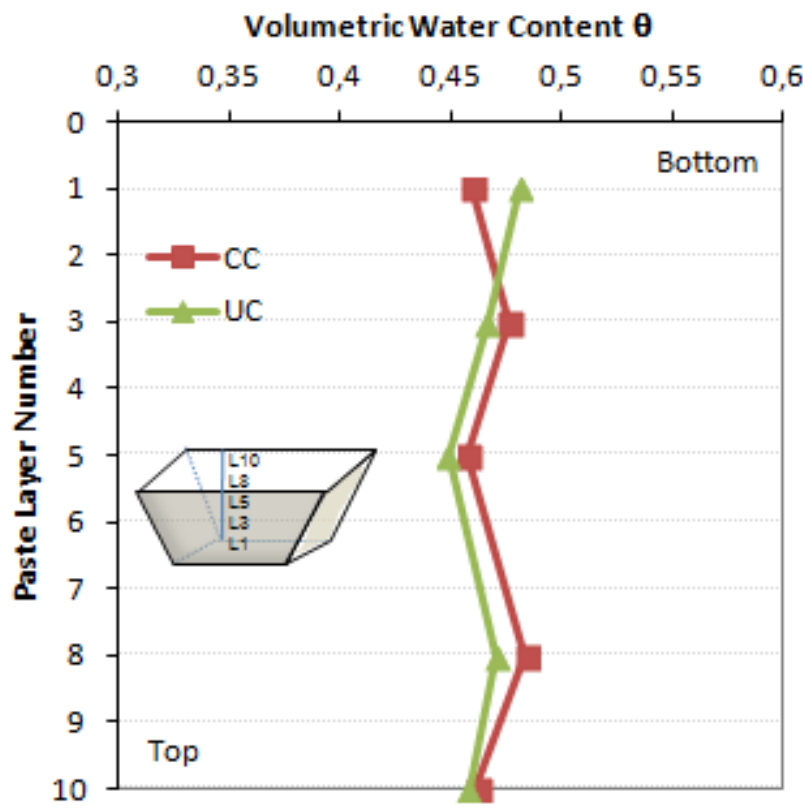

Figure 9. Change in the water content with paste layer addition

Figure 10 presents the variation in degree of saturation of paste tailings layers in both cemented cell CC and uncemented cell UC with elapsed time. As expected, the bottom paste tailings layers (Layers 1 and 3) are more saturated than top paste tailings layers primarily attributable to the consolidation settlements which may significantly decrease apparent void spaces among paste tailings solid grains. For fine-sized paste tailings, thinlyplaced paste tailings layers present faster settlement than thickly-placed tailings layers. The degree of saturation of paste tailings varies between $94 \%$ and $100 \%$ and then reaches a plateau following a slight increase after the deposition process of paste tailings layers is completed fully. Paste tailings layers 1,3 and 8 , respectively provide a degree of saturation close to $100 \%$. Due to the fact that the first paste tailings layer is cemented (2wt\%) in the cemented cell filling configuration, and acts as a barrier cover, the layers in the cemented cell regime keeps more free water within the paste tailings matrix than the ones of uncemented cell, resulting in higher degree ofsaturation.

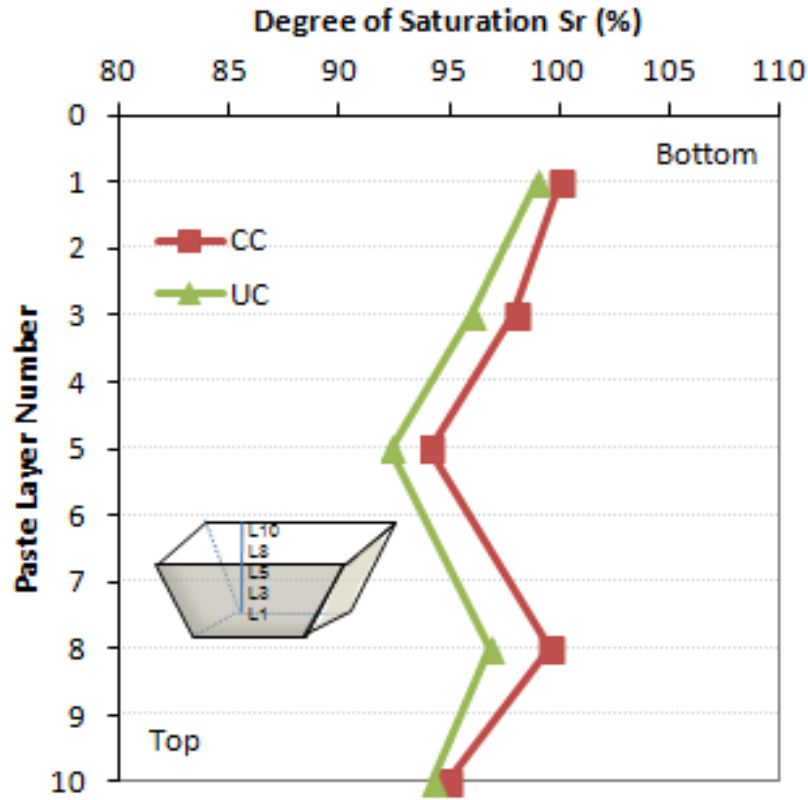

Figure 10. Change in the degree of saturation with paste layer addition

3.4. Effect of stress and drainage conditions on geotechnical properties of paste backfills

Figure 11 shows a variation of gravimetric water content, porosity and degree of saturation of different paste backfills containing a mean cement content of $4.5 \%$ (i.e., consolidated, drained and non-drained as control) as a function of curing time. The lowest values were gained from consolidated paste backfills at different curing times, irrespective of curing age. For a $4.5 \mathrm{wt} \%$ cement, water content decreased from $18.7 \%$ to $13.2 \%$ for consolidated paste backfills, from $20.8 \%$ to $18.5 \%$ for drained paste backfills, and from $25.1 \%$ to $24.2 \%$ for the undrained paste backfills, when the equivalent curing time increased from 7 to 28 days (Figure 11a). Water content is governed by the final water-to-cement ratios of samples and the quantity of the excess water needed for cement hydration products. In general, consolidated paste backfills where stress is incrementally applied during the early stages of curing contain less water in their own structures, when comparing with both drained and undrained cemented paste fills where no stress is applied to samples. Figure $11 \mathrm{~b}$ shows that porosity is nearly steady over time for all the samples. Porosity varies from 0.41 to 0.4 for consolidated samples, from 0.44 to 0.43 for drained samples, and from 0.48 to 0.47 for non-drained samples when curing age is increased from 7 to 28 days. The reduction in porosity may be explained by the rearrangement of particles in the backfill after applying consolidation loadings (drainage of excessive water and thus reduced porosity). The quantity of cement added is related to cementitious materials. This means that the higher are the cement and curing time, the greater are cement hydration products and reduced porosity. Figure 11c shows evolution of degree of saturation with curing time for different backfills. The degree of saturation notably reduces with time, regardless of type of samples tested. The highest reduction in the degree of saturation was obtained from consolidated paste backfills. At 28 days, the degree of saturation was $86 \%, 88 \%$ and $93 \%$ for consolidated, drained and undrained paste backfills, respectively. It is noteworthy that variation of the degree of saturation in undrained paste backfills was limited (on average varies $95-93 \%$ ) for a given curing time. 


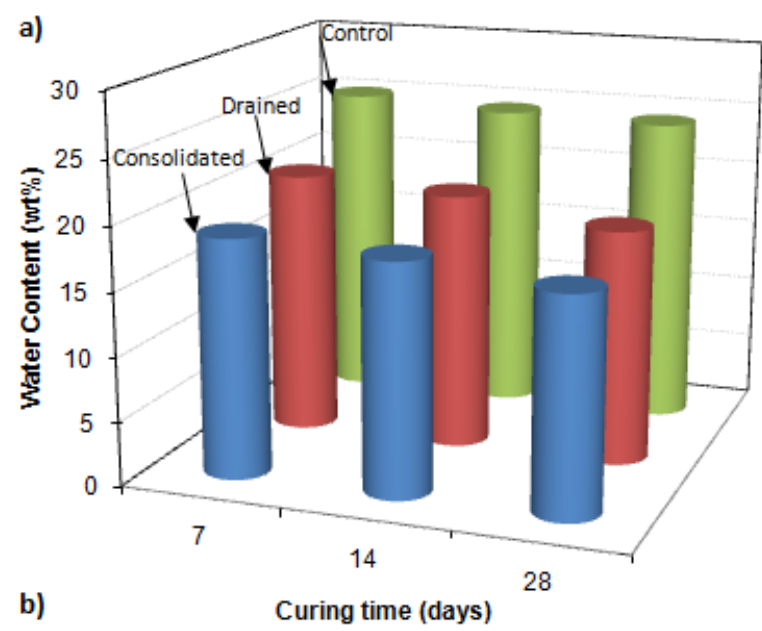

b)

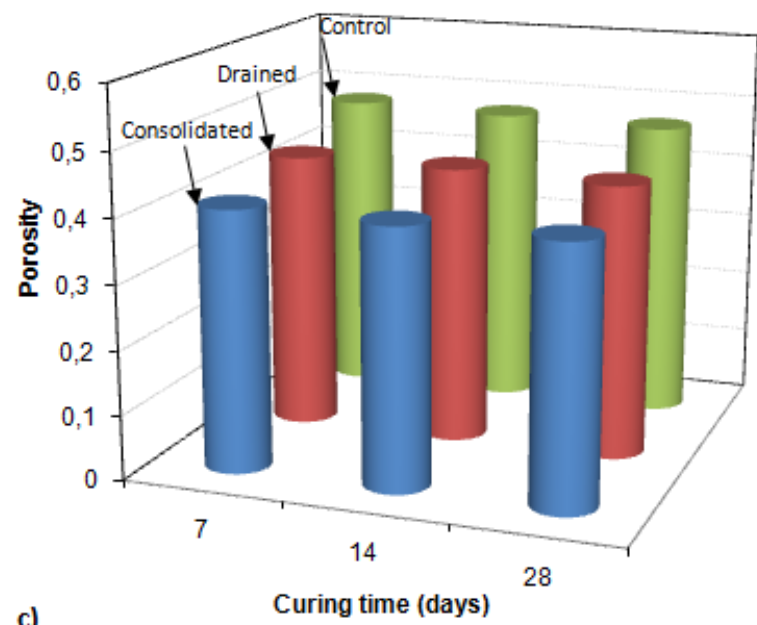

c)

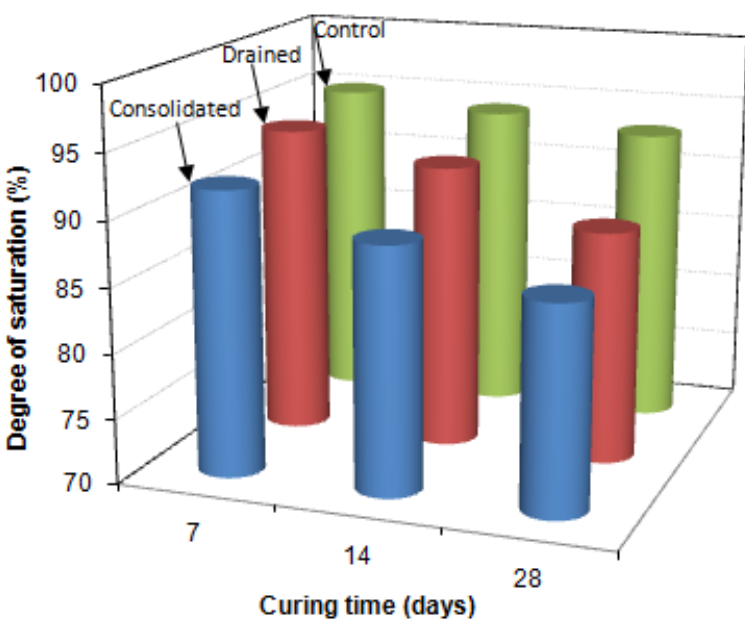

Figure 11. Change in water content (a), porosity (b) and degree of saturation (c) with different paste backfills

\subsection{Effect of binder content and drainage conditions on pore structure of paste backfills}

Pore structure is an important microstructural characteristic of a porous matrix, as it affects the physical and mechanical properties and controls the durability of cemented materials such as CPB. The behavior of a porous material is strongly affected by the distribution of pores of various sizes within the solid. In this regard, the two different microstructural tests were experimentally undertaken on cemented paste backfill and surface paste disposal samples and the obtained results were presented in Figure 12. For the SPD applications, the MIP results indicate that the total porosity $n_{\text {tot }}$ was $48.6 \%$ for uncemented paste tailings and $45.4 \%$ for paste tailings containing $2 \mathrm{wt} \%$ normal Portland cement (referred to as paste backfill). The critical pore diameter $d_{\mathrm{cr}}$ was $0.5 \mu \mathrm{m}$ and $1.3 \mu \mathrm{m}$ for uncemented and cemented paste fill, respectively. The observed difference between paste tailings without cement and $2 \%$ cemented fill justifies an evolution of texture and pore structure as a function of binder type and amount used in the backfill mixes and its cement hydration products (as the pores within the paste backfill are filled fully by the hydrates or precipitates).
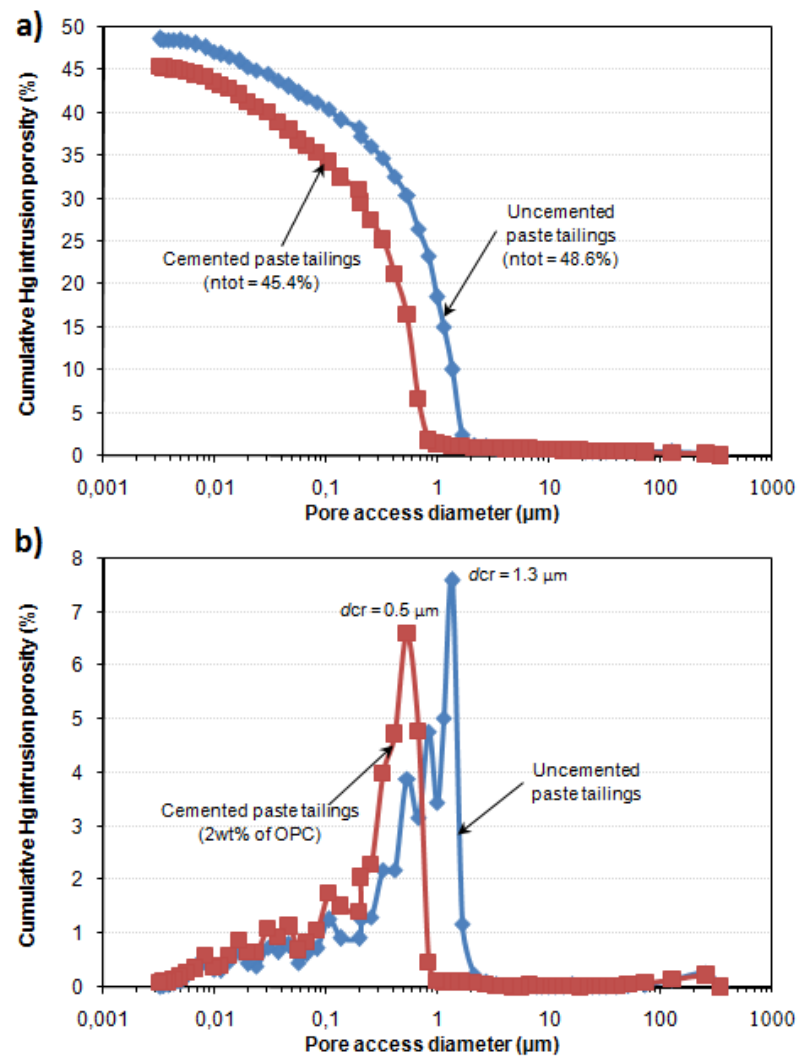

Figure 12. Pore size distribution of surface paste disposal samples: a) cumulative and b) incremental curves

Figure 13 shows the change in pore size distribution curves for 28-day cured CPB samples with a binder content of $4.5 \%$. The MIP total porosity $n_{\text {tot }}$ corresponds to the last recorded point (or the highest intrusion pressure and the smallest equivalent pore throat size). The consolidated backfills constantly show lower total porosity $n_{\text {tot }}(38.4 \%)$ than that of undrained ones (45.8\%). The curing conditions (with and without pressure during curing) play a role in total porosity $n_{\text {tot }}$ of CPB samples for a given binder content. The effective curing conditions (the combined effects of applied pressure and drainage on consolidated backfills) appear to accelerate the cementitious processes by the formation of increasing amounts of cementitious products in a mechanically-reduced pore space. However, hydration and/or precipitation appear to occur to a lesser extent in the undrained backfills that are not allowed to drain. As a result, the porosity of undrained backfills is greater than that of consolidated backfills. The pore size distribution curves are dependent on water-to-cement $(w / c)$ ratio. The $w / c$ ratio of consolidated backfills decreases with the removal of 
excess water from samples due to the applied pressure during curing. The reduction in $w / c$ ratio is accompanied by a reduction in $n_{\text {tot, }}$ which could be explained partially by a reduction in pore size as pores are partially filled by hydrates and/or precipitates.
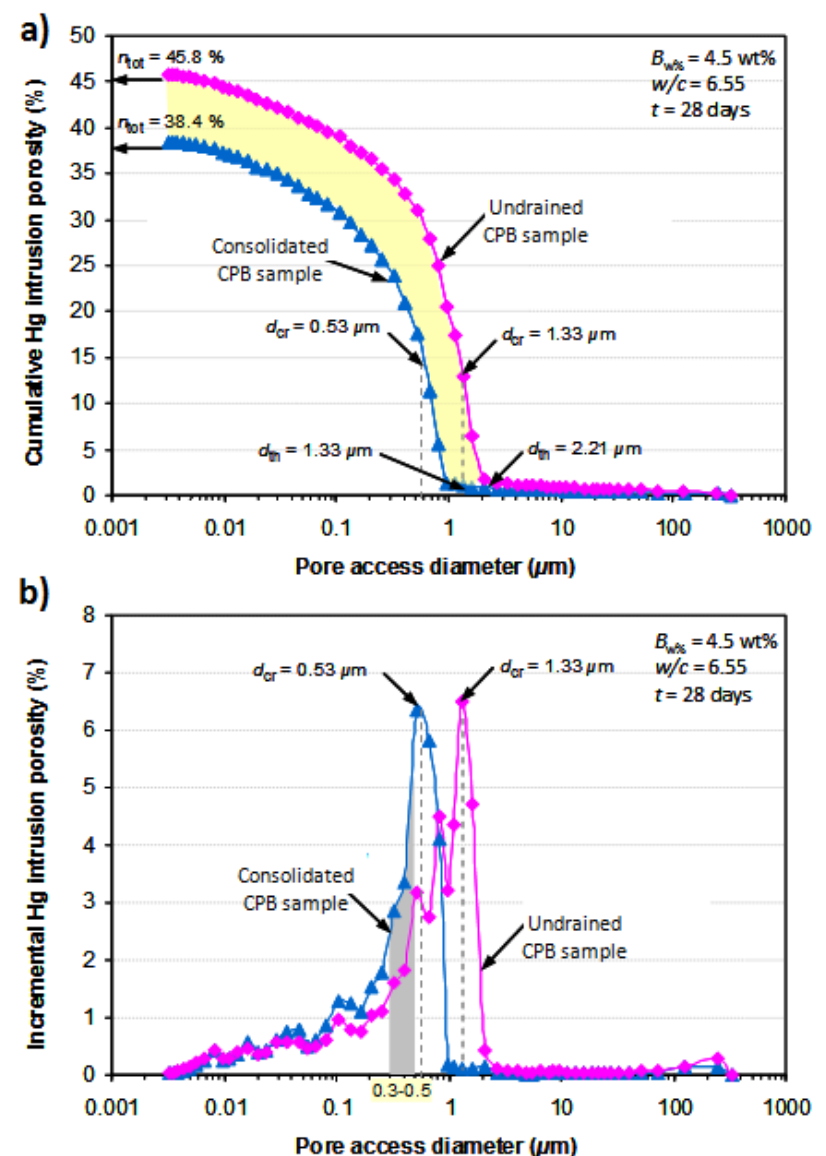

Figure 13. Pore size distribution of cemented paste backfill samples: a) cumulative and b) incremental curves

\subsection{Assessment of geochemical test results}

Table 2 lists a variation of $\mathrm{pH}$, redox potential Eh, electrical conductivity EC and alkalinity of water drained from samples with $4.5 \mathrm{wt} \%$ cement. One can say that $\mathrm{pH}, \mathrm{EC}$ and alkalinity decrease while Eh increases with increasing curing age. $\mathrm{pH}$ drops dimly from 11.8 to 10.7 for consolidated samples and from 11.6 to 10.9 for drained samples when the curing time increased from 7 to 28 days. The uppermost Eh values were obtained from 28-day cured samples. Eh varied between 173 and $221 \mathrm{mV}$ for both consolidated and drained samples. EC reduces from 6.1 to $5.5 \mathrm{mS} / \mathrm{cm}$ for consolidated backfills, from 7.2 to $5.8 \mathrm{mS} / \mathrm{cm}$ for drained backfills, when the curing is increased from 7 to 28 days. The reduction in EC can be well explained by the loss of conducting ions from solution. The

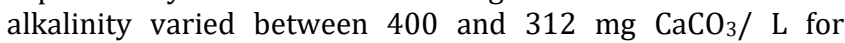
consolidated samples, between 396 and $348 \mathrm{mg} \mathrm{CaCO}_{3} / \mathrm{L}$ for drained samples. The alkalinity was high at 7 days and tends to decrease with increasing curing. This is due to the increase of $\mathrm{pH}$ after cement addition to the mix.

Figure 14 shows the evolution of $\mathrm{pH}$ and Eh of drainage waters for each field cell. One can say that $\mathrm{pH}$ of water drained from CC varies between 6.8 and 7.9 while $\mathrm{pH}$ of water drained from uncemented cell varies between 7.2 and 6.9. The oxidation of pyritic minerals in the tailings causes a decrease in $\mathrm{pH}$. But if cemented tailings are used, then $\mathrm{pH}$ increases because of an alkaline medium, as in case of cemented cell.
Table 2. Geochemical results of laboratory-prepared samples

\begin{tabular}{lllll}
\hline $\begin{array}{l}\text { Curing } \\
\text { (days) }\end{array}$ & $\mathrm{pH}$ & $\begin{array}{l}\mathrm{EC} \\
(\mathrm{mS} / \mathrm{cm})\end{array}$ & $\begin{array}{l}\text { Eh } \\
(\mathrm{mV})\end{array}$ & $\begin{array}{l}\text { Alkalinity } \\
\left(\mathrm{mg} \mathrm{CaCO}_{3} / \mathrm{L}\right)\end{array}$ \\
\hline \multicolumn{5}{l}{ Consolidated paste backfills } \\
\hline 7 & 11.8 & 6.1 & 173 & 400 \\
14 & 11.3 & 5.8 & 185 & 358 \\
28 & 10.7 & 5.5 & 204 & 312 \\
\hline \multicolumn{5}{l}{ Drained paste backfills } \\
\hline 7 & 11.6 & 7.2 & 189 & 396 \\
14 & 11.4 & 6.7 & 208 & 372 \\
28 & 10.9 & 5.8 & 221 & 348
\end{tabular}

*EC: Electrical conductivity; Eh: oxidation reduction potential

One can notice that, after Layer 8, pH of water drained from UC is lower than that of CC. This can be well explained by surface cracks where oxygen may enter in the bottom of the cell and therefore result in lower $\mathrm{pH}$ over time (Figure 14a). Eh of leachate water increases from $179 \mathrm{mV}$ to $259 \mathrm{mV}$ for CC and from $181 \mathrm{mV}$ to $356 \mathrm{mV}$ for UC (Figure 14b), mainly due to the release of heavy metals from paste tailings. One can speak that Eh is closely related to acidic and basic solutions as well as degree of saturation. When the Eh parameter becomes positive, the solution contains oxidizing compounds. Eh also increases with reduced degree of saturation which contributes to a major increase of oxidation by molecular oxygen diffusing through leachate water. Eh increases faintly, resulting in a release of free ions in solution (e.g., sulfate).
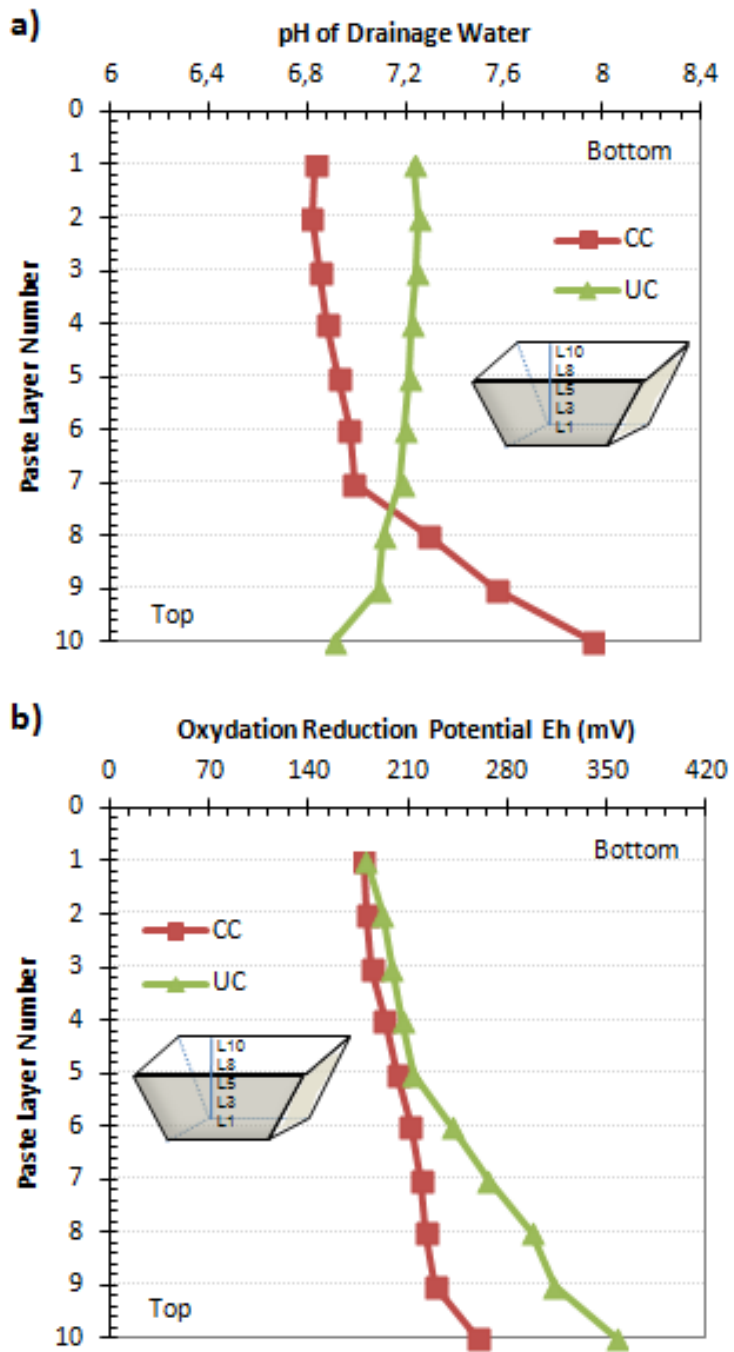

Figure 14. Variation of a) pH, b) Eh with paste layer 
Figure 15 also presents an evolution of electrical conductivity $\mathrm{EC}$ and sulfate $\mathrm{SO}_{4}{ }^{2-}$ of the collected leachate water with time from field experimental cell. EC decreases slightly from 6.4 to $4.9 \mathrm{mS} / \mathrm{cm}$ for CC and from 6.0 to $4.5 \mathrm{mS} / \mathrm{cm}$ for UC, as paste layer is increased from 1 to 10 . The cogent reason behind the reduction of EC can be well explained with the decrease in the total dissolved solids concentration from the solution (Figure 15a). The mineralogy of tailings and binders can also affect backfill strength by influencing certain chemical reactions that occur during curing. Figure $15 \mathrm{~d}$ shows the release of sulfate from paste tailings layers in each cell. One can say that the sulfate released from CC is relatively higher than that of UC for a given paste layer. The sulfate concentration reduces from $4160 \mathrm{mg} / \mathrm{L}$ to $2918 \mathrm{mg} / \mathrm{L}$ for CC and from $4095 \mathrm{mg} / \mathrm{L}$ to 2457 $\mathrm{mg} / \mathrm{L}$ for UC. Due to the fact that paste tailings layers contain a relatively high sulfide mineral $(\sim 30 \mathrm{wt} \%)$ and tend to generate sulfate $\mathrm{SO}_{4}^{-2}$ due to sulfide oxidation by oxygen intake from air. The cogent reason why the sulfate released from CC is higher than UC is owing to the cement which can take place the dissolution of the sulfates present in the cement. A slight quantity of $\mathrm{SO}_{4}{ }^{2-}$ in the dissolved cement is lost through the drainage as a result of self-weight consolidation settlement. The concentration of sulfate ions decreases as they react with the cement hydrations products. In the presence of oxygen and water, sulfide minerals such as pyrite in tailings can be oxidized producing sulfate phases.

a)

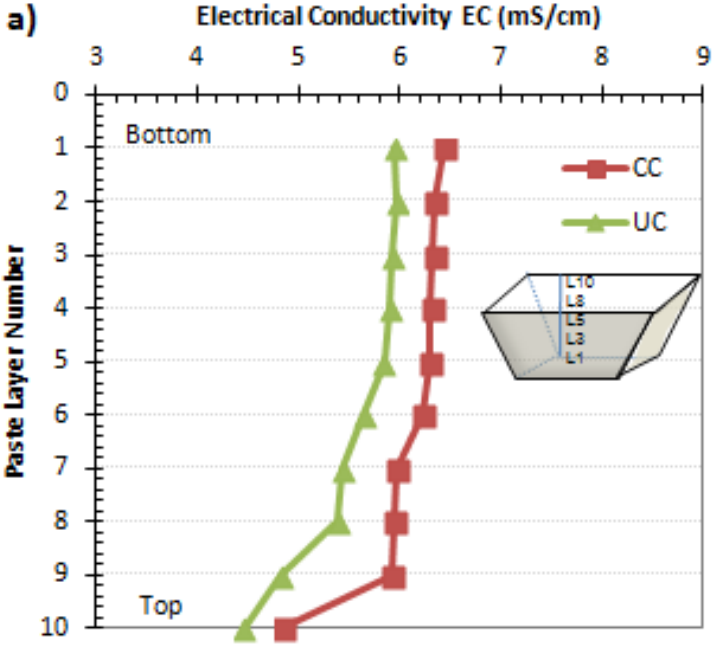

b) Sulfate Concentration $5042-(\mathrm{mg} / \mathrm{L})$

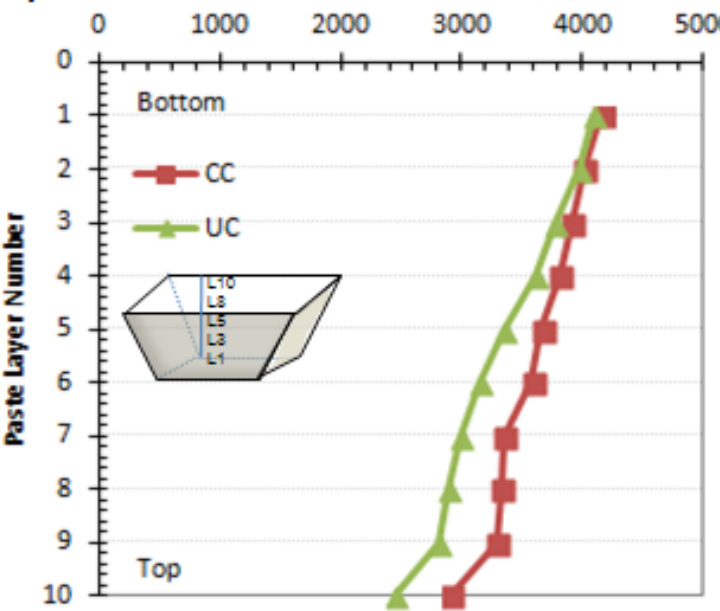

Figure 15. Variation of a) EC, and b) $\mathrm{SO}_{4}{ }^{2-}$ with paste layer

\section{Conclusions}

This study presents the results of the works intended for both underground paste backfill and surface paste tailings disposal applications. A number of laboratory and field testing were done on the paste tailings received from a Canadian hard rock mine. Laboratory investigation included mechanical testing, geotechnical and microstructural testing on the consolidated, drained and undrained paste backfills with $4.5 \mathrm{wt} \%$ cement at curing of 7, 14 and 28 days while field investigation included volumetric water content and degree of saturation of paste tailings disposed in two mini cells with and without cement. Only $2 \mathrm{wt} \%$ cement was used for paste tailings placed in Layer 1 of cemented cell. Based on the different laboratory and field test results, the following conclusions can be drawn:

$\checkmark$ The best ideal paste backfill mixes were obtained from the consolidated paste backfills when comparing with the others: both drained and undrained backfills.

$\checkmark$ Application of consolidation stress to laboratory-made paste backfills during curing imitates the paste backfill's field conditions which must be considered for a capable backfill design for modern mines.

$\checkmark$ Addition of cement to the tailings layers practiced in field cells plays an important role on quality and behavior of surface paste disposal.

$\checkmark$ Surface paste disposal method can be implemented over conventional tailings dams to reduce waste management and future reclamation costs.

These results advice that consolidated backfills done using a new laboratory tool can be well used for cost and performance effective paste backfills instead of both drained and undrained backfills done using conventional moulds. Also, the suggested new approach for surface disposal of hazardous paste tailings allows mining operators to reduce waste treatment- and management-related costs. As a final point, additional work is in progress to validate the common benefits of underground paste backfill and surface paste disposal test results.

\section{References}

[1] Aubertin, M., Bussière, B. and Bernier, L., "Environnement et Gestion des Résidus Miniers", Université du Québec en Abitibi-Témiscamingue (UQAT), Rouyn-Noranda, Québec, Canada, 1-210, 2002.

[2] Yilmaz, E., Kesimal, A. and Ercikdi, B., "Evaluation of acid producing sulphidic mine tailings as a paste backfill", Turkish Journal of Earth Sciences Review, 17, 11-19, 2004.

[3] Schoenberger, E., "Environmentally sustainable mining: the case of tailings storage facilities", International Journal of Resources Policy, 49, 119-128, 2016.

[4] Lotermoser, B., "Mine Wastes: Characterization, Treatment and Environmental Impacts", Springer, 1-400, 2010.

[5] Karaoglu, K. and Yilmaz, E., "Cemented paste backfill pressure monitoring and field testing", Paste tailings Management, Springer, Cham, 195-214, 2017.

[6] Yilmaz, E., Kesimal, A. and Ercikdi, B., "The factors affecting the strength and stability of paste backfill", Turkish Journal of Earth Sciences, 28, 2, 155-169, 2003.

[7] Yilmaz, E. and Fall, M., "Paste Tailings Management", Springer International Publishing, 1-303, 2017.

[8] Adiansyah, J., Rosano, M., Vink, S. and Keir, G., "A framework for a sustainable approach to tailings management: disposal strategies", Journal of Cleaner Production, 108, 1050-1062, 2015.

[9] Kesimal, A., Yilmaz, E., Ercikdi, B., Alp, I., Yumlu, M. and Ozdemir, B., "Laboratory testing of cemented paste backfill", Madencilik, 41, 4, 11-20, 2002. 
[10] Kesimal, A., Yilmaz, E., Ercikdi, B., Alp, I., Yumlu, M. and Ozdemir, B., "Paste backfill technology in underground mining: A case study", Turkish Journal of Earth Sciences Review, 16, 1, 45-53, 2003.

[11] Yilmaz, E., Belem, T., Benzaazoua, M. and Bussière, B., "Assessment of the modified CUAPS apparatus to estimate in situ properties of cemented paste backfill", ASTM Geotechnical Testing Journal, 33, 1-12, 2010.

[12] Yilmaz, E., Benzaazoua, M., Bussière, B. and Pouliot, S., "Influence of disposal configurations on hydrogeological behaviour of surface paste disposal: A field experimental study", International Journal of Minerals Engineering, 131, 12-25, 2014.

[13] Bussière, B., "Hydrogeotechnical properties of tailings from mines and emerging geoenvironmental disposal approaches", Canadian Geotechnical Journal, 44, 1019 1052, 2007.

[14] Boger, D., "Personal perspective on paste and thickened tailings: A decade on", Mining Technology - Transactions of the Institutions of Mining and Metallurgy: Section A, 121, 29-36, 2012.

[15] Simon, D. and Grabinsky, M.W., "Apparent yield stress measurement in cemented paste backfill", International Journal of Mining, Reclamation and Environment, 27, 231256, 2013.

[16] Li, W., Hou, Y. and Han, S., "GGBFS effect on relationship between strength and elastic modulus of backfill", The Electronic Journal of Geotechnical Engineering, 21, 18971907, 2016.

[17] Tariq, A. and Yanful, E.K., "A review of binders used in cemented tailings for underground and surface disposal practices", Journal of Environmental Management, 131, 138-149, 2013.

[18] Belem, T. and Benzaazoua, M., "Design and application of underground mine pastefill technology", Geotechnical and Geological Engineering, 26, 2, 147-174, 2008.

[19] Benzaazoua, M., Fall, M. and Belem, T., "A contribution to understanding the hardening process of cemented pastefill", Minerals Engineering, 17, 2, 141-152, 2004.

[20] Cihangir, F., Ercikdi, B., Kesimal, A., Turan, A. and Deveci, H., 2012. "Utilisation of alkali-activated blast furnace slag in paste backfill of sulphide mill tailings: Effect of binder type and dosage", Minerals Engineering, 30, 33-43.

[21] Yilmaz, E., Belem, T., Benzaazoua, M., Kesimal, A. and Ercikdi, B., "Evaluation of the strength properties of deslimed tailings paste backfill", Mineral Resources Engineering, 12, 2, 129-144, 2007.

[22] Ercikdi, B., Cihangir, F., Kesimal, A., Deveci, H. and Alp, I., "Effect of natural puzzolans as mineral admixture on the performance of cemented fill of sulphide-rich tailings", Waste Management Resources, 28, 430-435, 2010.

[23] Fall, M. and Benzaazoua, M., "Modeling the effect of sulphate on strength development of paste backfill and binder mix optimization", Cement and Concrete Research, 35, 301-314, 2005.

[24] Koohestani, B., Belem, T., Koubaa, A. and Bussière, B, "Experimental investigation into strength development of cemented paste backfill containing nano-silica", Cement and Concrete Composites, 72, 180-189, 2016.

[25] El Mkadmi, N., Aubertin, M. and Li, L., "Effect of drainage and sequential fill on behavior of paste backfill in mine stopes", Canadian Geotechnical Journal, 51, 1-15, 2014.

[26] Emad, M.Z., Mitri, H. and Kelly, C., "State-of-the-art review of backfill practices for sublevel stoping system", International Journal of Mining, Reclamation and Environment, 29, 544-556, 2015.
[27] Veenstra, R.L. Bawden, W., Grabinsky, M. and Thompson, B., "Matching stope scale numerical modeling results of early age cemented paste fill to in-situ instrumentation results", 64th Canadian Geotechnical Conference, Toronto, Ontario, Canada, 1-8, 2011.

[28] Benzaazoua, M., Belem, T. and Yilmaz, E., "Novel lab tool for paste fill", Canadian Mining Journal, 127, 31-31, 2006.

[29] Yilmaz, E., Belem, T. and Benzaazoua, M., "Specimen size effect on strength behavior of cemented paste backfills subjected to different placement conditions", Engineering Geology, 185, 52-62, 2015.

[30] Fahey, M., Helinski, M. and Fourie, A., "Development of specimen curing procedures that account for the effect of stress during curing on the strength of cemented backfill", Journal of Geotechnical and Geological Engineering, 29, 709-723, 2011.

[31] Daliri, F., Simms, P. and Sivathayalan, S., "Shear and dewatering behaviour of densified gold tailings in a laboratory simulation of multi-layer deposition", Canadian Geotechnical Journal, 53, 1246-1257, 2016.

[32] Deschamps, T., Benzaazoua, M., Bussière, B., Aubertin, M. and Belem, T., "Microstructural and geochemical evolution of tailings in surface storage", Minerals Engineering, 21, 341-353, 2008.

[33] Martin, V., Aubertin, M. and McMullen, J., "Surface disposal of paste tailings", 5th ICEG Environmental Geotechnics: Opportunities, Challenges and Responsibilities for Environmental Geotechnics, Cardiff, UK, 1471-1478, 2006. 